\title{
EFFECT OF HUMIDITY ON GROWTH AND DEVELOPMENT OF FUNGAL PATHOGENS OF RIPENING DATES (PHOENIX DACTYLIFERA L.) AT KHAIRPUR, PAKISTAN
}

\author{
Mirza Hussain ${ }^{1}$, Noor Jehan Ismailli' ${ }^{2}$, Absar Mithal Jiskani ${ }^{3}$ \\ ${ }^{1}$ Department of Botany, Government Girls Degree Science College, Gambat, Pakistan. \\ 2 Shah Abdul Latif University, Khairpur, Pakistan. \\ ${ }^{3}$ Department of Plant Pathology, Sindh Agriculture University, Tandojam, Pakistan.
}

\section{ART I CLE I N F O}

\section{Article history}

Received: 31 ${ }^{\text {st }}$ January, 2020

Revised: $19^{\text {th }}$ March, 2020

Accepted: 22 ${ }^{\text {nd }}$ March, 2020

\section{Keywords}

Humidity

Growth

Development

Fungal pathogens

Date palm

Sobho Dero Taluka
A B S T R A C T

\begin{abstract}
Pakistan is regarded as one of the top ranked date palm cultivated regions of the world. In Sindh province of Pakistan, date palm (Phoenix dactylifera L.) is mainly cultivated in Khairpur. Date palm holds a significant position in the socio-economic development at Khairpur where several thousand peoples are associated directly or indirectly with date palm cultivation, trade and market. Date palm requires high temperature and low humidity from flowering to fruiting and no rainfall during ripening. Unfortunately, in district Khairpur, during the period of rainfall, humidity becomes very high and temperature decreases. The periods of high humidity provide favorable conditions for the growth and development of fungal pathogens which cause severe losses in yield and quality of fruits. The present study was, therefore, conducted to find out the effect of humidity on the growth and development of fungal pathogens in three cultivars of dates viz. Aseel, Kupro and Khar at ripening stage due to moisturized weather conditions at Sobho Dero Taluka of district Khairpur. The symptoms of fungal attack such as cracking, blackening, blemishes and spoilage were observed on ripened fruits. Three fungi viz. Fusarium poae, Alternaria tenuis and Aspergillus niger were isolated from infected samples of three selected cultivars. The frequencies of occurrence of these fungi were 5.66, 6.33 and 8.33 respectively. It is concluded that incidence and prevalence of fungal pathogens greatly increased during rainy season which demand stringent surveillance and control measures to minimize the damage.
\end{abstract}

Corresponding Author: Mirza Hussain

Email: mirzasamo512@gmail.com

(C) 2020 EScience Press. All rights reserved.

\section{INTRODUCTION}

Date palm (Phoenix dactylifera L.) belongs to Arecaceae family (Angiosperms, monocotyledon) consisting of about 200 genera and more than 2,500 species. Phoenix (Coryphoideae phoeniceae) is one of the genera with approximately 14 species which are native to the tropical or subtropical regions of southern Asia or Africa, including Phoenix dactylifera L. (Eoin, 2016; Siddiq et al., 2013). It is considered as one of the oldest and main staple and ancient crops in Southwest Asia and North Africa (Abro et al., 1986; Al-Harrasi et al., 2014). It is commercially, economically, nutritionally and medicinally the most important crop (Ahmed and Farooqi, 1972; Ishtique and Tarique, 1988; Khuskh, 
1988). Pakistan is regarded as one of the top ranked date palm cultivated regions of the world. In Pakistan, date palm is mainly cultivated in Khairpur (Sindh) and Turbat (Balochistan) districts (Jatoi et al., 2009). Date palm holds a significant position in the socio-economic development at Khairpur where several thousand peoples are associated directly or indirectly with date palm cultivation, trade and market.

Date palm is prone to fungal diseases of economic importance because it contains essential nutrients which serve as good medium for several fungal species for their luxuriant growth (Hussain and Ismaili, 2019; Ismailli et al., 2003). Dates are easily spoilt during rainy season when climatic conditions are highly humid (Hussain, 2012; Ismailli et al., 1993; Mahar, 1998; Mahar and Bhatti, 1994). A great deal of fungi affect date palm production due to conducive environmental conditions, which cause serious damage (Chaughtai, 1986; Sharma and Mukerji, 1976). About 550 million tons of total crop production (16\%) in the world is lost every year owing to fungal diseases.

It is well known that weather factors affect host and pathogen in a complex way during disease development. Diurnal and seasonal variations of weather of a particular locality influence the incidence of diseases by airborne fungal pathogens. Rain and rain splash aid dispersal and infection of fungal pathogens of dates

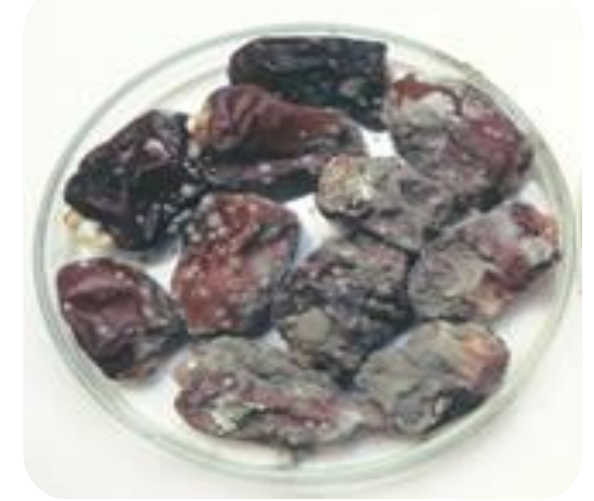

Figure 1. Fungal infected samples.

Isolation of fungi from infected samples: Czepek's Dox Agar medium was used for the isolation of fungal pathogens. The medium in the Petri plates was inoculated with the infected parts of date fruits. The inoculated plates were incubated at $29^{\circ} \mathrm{C}$ for 7 days. The individual colonies were picked and placed on fresh
(Ismailli, 1999.). In Khairpur district of Sindh, occasional monsoon rainfalls during the months of July to August cause heavy damage to mature dates. The humidity is at the maximum during the monsoon months and increases the damage by creating conditions favorable for microorganisms such as yeasts, fungi and bacteria etc. Amongst microorganisms, the fungi are causing more damages to crops. In Khairpur district, fungal infection is the major problem wherever the date palms are grown and incurs considerable losses to dates. Keeping in view the above mentioned facts, in the present study, fungi infecting dates during the monsoon were isolated and identified with the objective to suggest control strategies to cure these fungi.

\section{MATERIALS AND METHODS}

Sample collection: During rainfall, infected samples of date fruits (Figure 1) of different varieties i.e. Aseel, Khar and Kupro were collected at ripening stage from the experimental area of Taluka Sobho Dero of Khairpur with the help of sterilized forceps and scissors into polythene bags. Sobho Dero is a town in the Khairpur District of Sindh province, Pakistan. It is located at $27^{\circ} 18^{\prime} 0 \mathrm{~N} 68^{\circ} 24^{\prime} 0 \mathrm{E}$ with an altitude of 46 meters (154 feet). Humidity above $50 \%$ was recorded during sampling time. The samples were brought to the laboratory for isolation and identification of fungal pathogens (Soomro, 1990.).

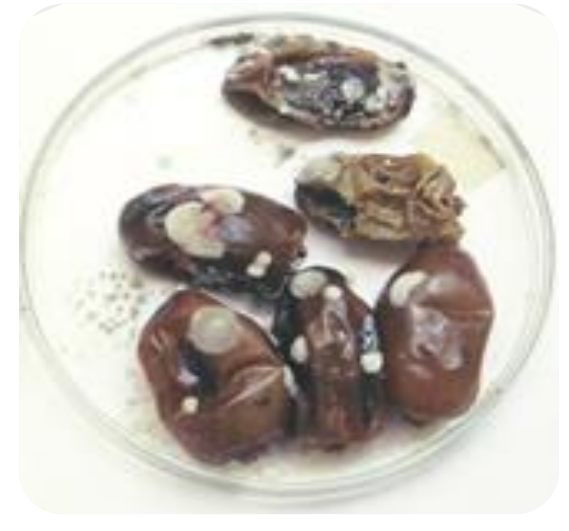

medium in the Petri plates for purification of the fungi (Figure 2).

Identification of fungi: The fungi were identified on the basis of different keys (Al-Yasiri et al., 2010; Cook, 1963; Gilman, 1975; Maitlo et al., 2013; Markhand et al., 2010; Thom and Raper, 1945). 

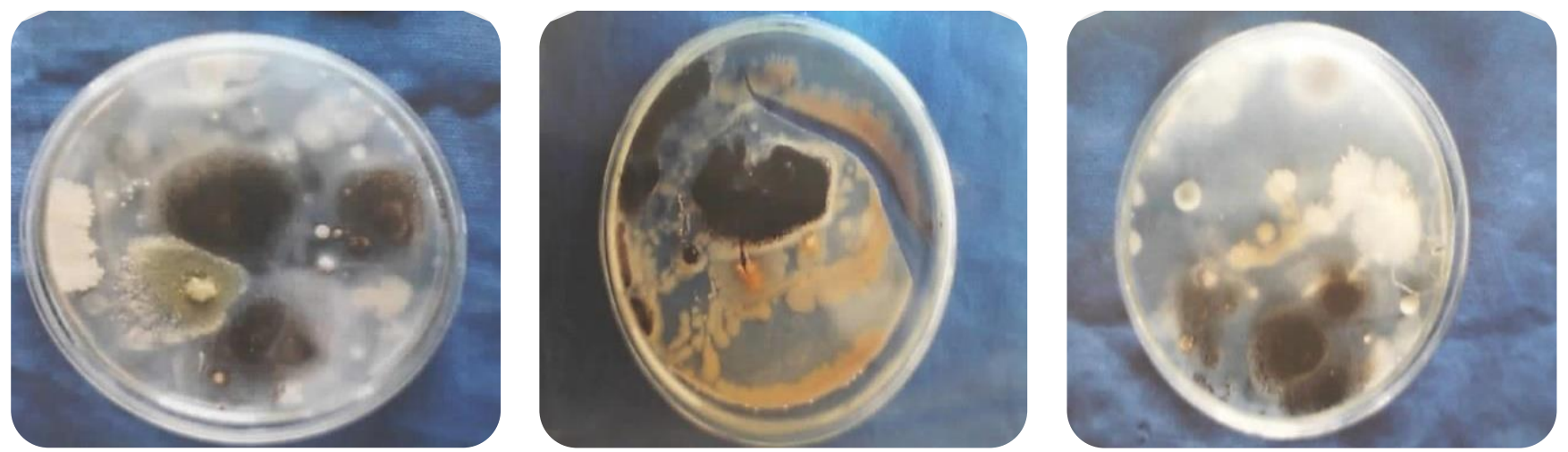

Figure 2. Media plates showing growth of different fungi.

\section{RESULTS AND DISCUSSION}

Three fungi viz., Fusarium poae, Alternaria tenuis and Aspergillus niger were isolated and identified on the basis of morphological characters from the ripening fruits of date varieties. The fungus $F$. poae was isolated from Kupro, A. tenuis from Aseel and A. niger from Kupro (figure 3, 4,5). The overall frequency of these three fungi is given in figure 6 . During the study, the role of rainfall was also investigated on the prevalence of fungal pathogens. The minimum humidity of $21 \%$ was recorded during March and April whereas it was the maximum during rainy season. The high humidity resulted in the increase in the prevalence of these fungi by creating favorable conditions for the fungi. It was found that the incidence and prevalence of fungal pathogens greatly increased during rainy season and caused much damage to dates (Markhand et al., 2010).
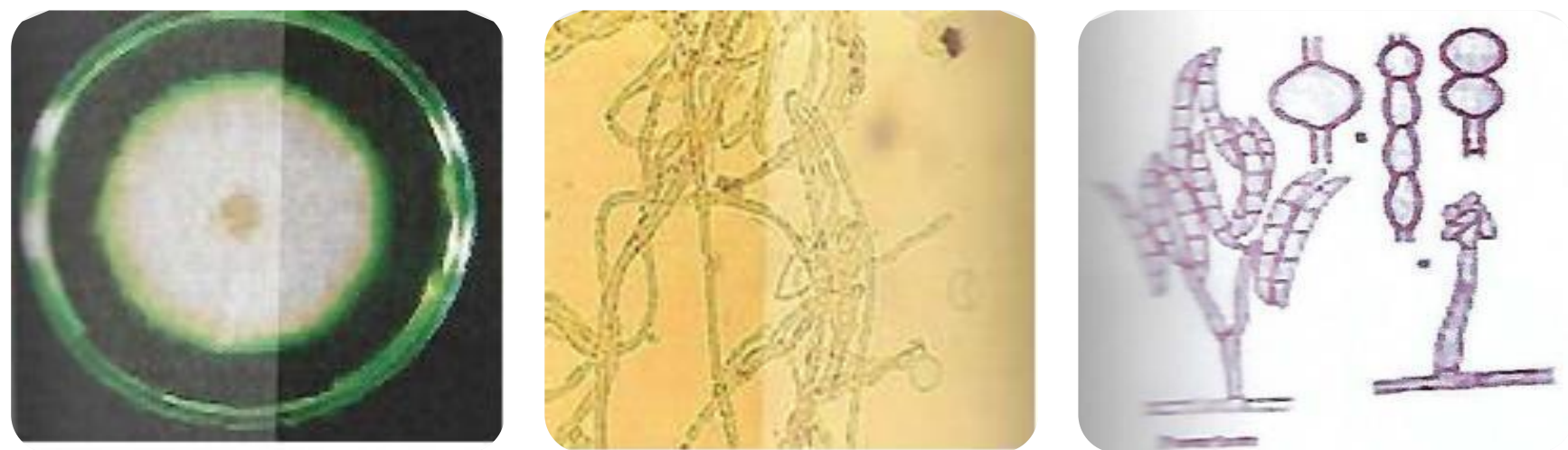

Figure 3. Fusarium poae (A) Growth on Czpek's Dox Medium (B) Microstructures (C) Conidiophore
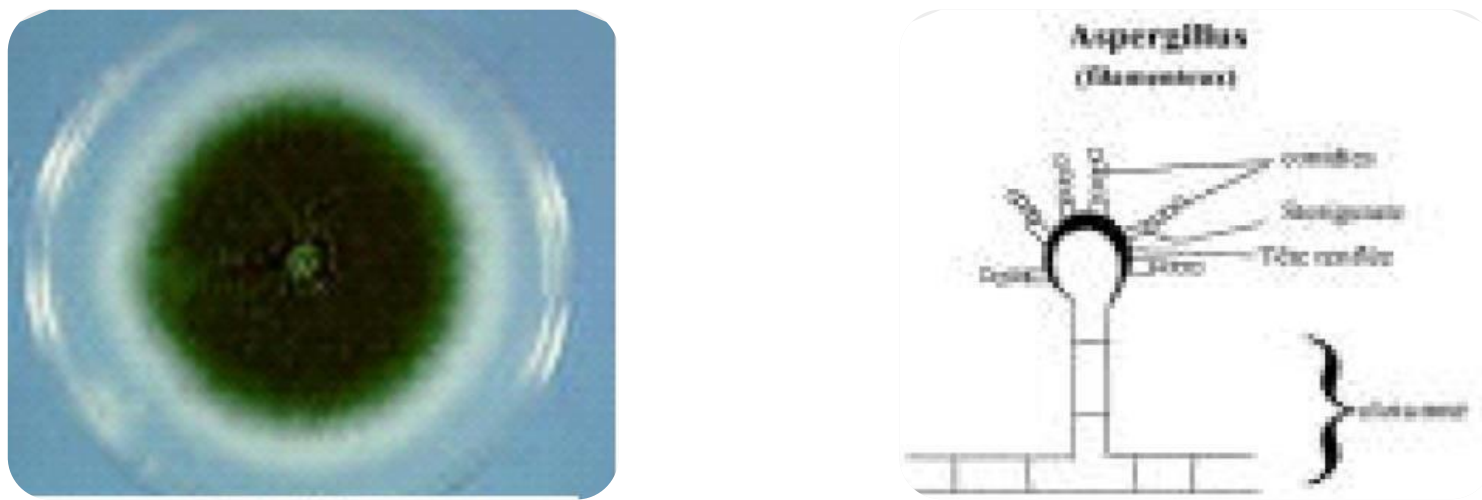

Figure 4. Aspergillus niger (A) Growth on Czpek's Dox medium (B) Micro structures (Conidiophorss with conidia) 

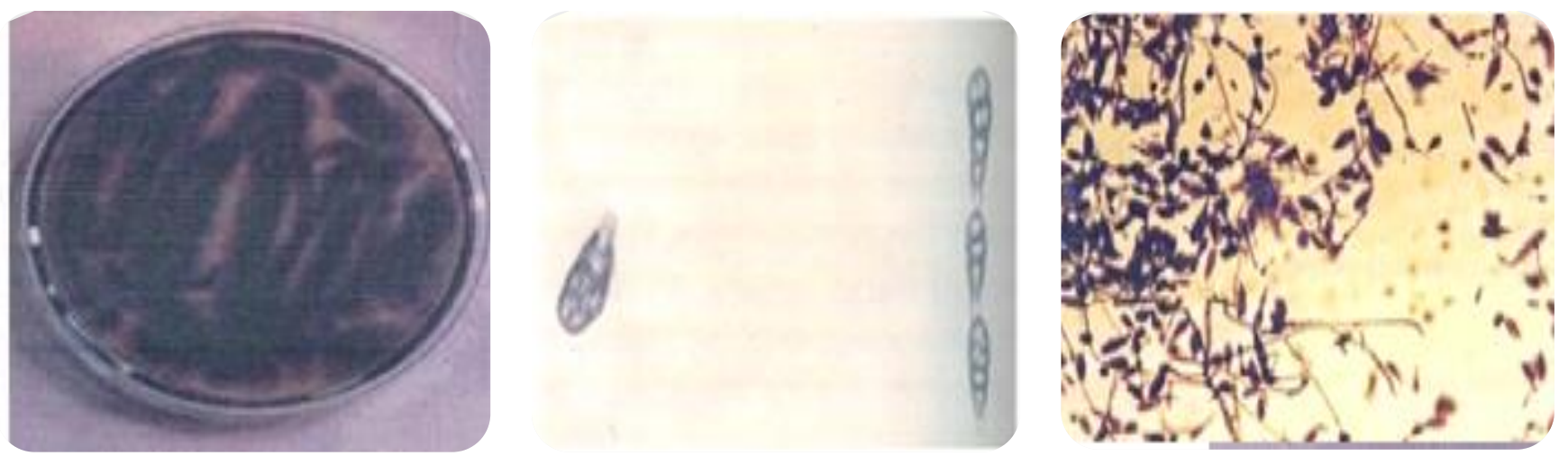

Figure 5. Alternaria lenuis (A) Growth on Czpek's Dox Medium (B) Conidia (C) Condiophores

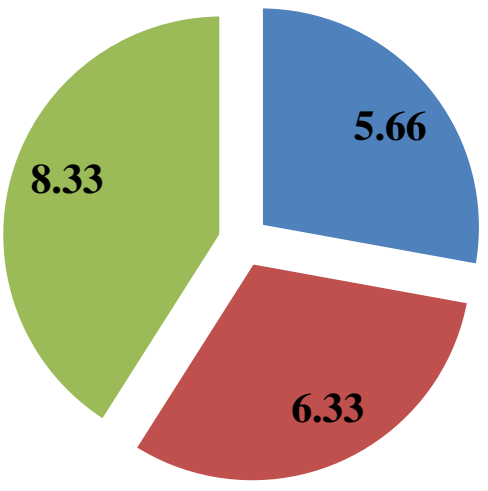

\section{- Fusarium poae $\quad$ Alternaria tenuis $\quad$ Aspergillus niger}

Figure 6. The overall frequency of occurrence of different fungi in Khairpur.

Humidity, similar to temperature, impacts the initiation and development of infectious plant diseases in many interrelated ways. It may exist as rain on the plant surface as relative humidity in the air, and as dew. Humidity is essential for the germination of fungal spores and penetration of the host by the germ tube. It is also vital for the activation of fungal pathogens before they can infect the plant. Moisture, in the form of splashing rain and running water, also plays an important role in the distribution and spread of many of these pathogens on the same plant and on their spread from one plant to another. Finally, moisture increases the succulence of host plants and thus their susceptibility to certain pathogens, which affects the extent and severity of disease. The occurrence of many diseases in a particular region is closely correlated with the amount and distribution of rainfall within the year.
Therefore, many diseases have been found to be severe in areas of high rainfall or high relative humidity during the growing season. In case of these diseases, the rainfall determines not only the severity of the disease, but also whether the disease will even occur in a given season. In fungal diseases, moisture affects fungal spore formation, longevity, and particularly the germination of spores, which requires a film of water covering the tissues. In many fungi, moisture also affects the release of spores from the fruiting bodies, which can occur only in the presence of moisture. The number of infection cycles per season of many fungal diseases is closely interrelated with the number of rainfalls per season. Thus in case of fungi infecting date palm trees, constant moistening of fruits for sufficient time is required for any infection to take place even at the optimum temperature range of the pathogen. At lower or higher temperatures the minimum 
wetting period required becomes higher. Similar conditions are required for the initiation and development of infections in many other diseases. If the length of the wetting period is less than the minimum required for the particular temperature, the pathogen fails to establish itself in the host and fails to produce disease (Agrios, 2005; Bowen, 2006; Vidhyasekaran, 2004).

\section{CONCLUSION}

It is concluded that high humidity provides favorable conditions for growth and development of fungal pathogens of dates. Three fungi viz. F. poae, A. tenuis and $A$. niger were found infecting different date palm varieties in Taluka Sobho Dero of Khairpur District, Sindh which demands stringent surveillance and control measures to minimize the damage.

\section{CONFLICT OF INTEREST}

The authors declare no conflict of interest.

\section{AUTHORS' CONTRIBUTION}

$\mathrm{MH}, \mathrm{NJI}$ and AMJ designed the study, MH and NJI executed the experiment, collected and analyzed the data and wrote the manuscript. AMJ edited the manuscript. All the authors approved the final manuscript.

\section{REFERENCES}

Abro, H.W., Sheikh, M., Khan, M., 1986. Studies of aerial mycoflora of the university campus area, Sindh University. Research Journal Science Series. 18, 185-186.

Agrios, G.N., 2005. Plant Pathology. 5th edition. Elsevier Academic Press 30 Corporate Drive, Suite 400, Burlington, MA 01803, USA.

Ahmed, S., Farooqi, W.A., 1972. Studies on some distinguishing characters of Iraqi dates at Jhang. Punjab Fruit Journal (Date Palm Number). 33, 136-147.

Al-Harrasi, A., Rehman, N.U., Hussain, J., Khan, A.L., AlRawahi, A., Gilani, S.A., Al-Broumi, M., Ali, L., 2014. Nutritional assessment and antioxidant analysis of 22 date palm (Phoenix dactylifera) varieties growing in Sultanate of Oman. Asian Pacific Journal of Tropical Medicine 7, 591-598.

Al-Yasiri, I.I., Saad, N.A., Nasser, A.R., Hassan, S.A., Zaid, K.M., 2010. The relationship between the fungus Fusarium solani and some pathological phenomena on date palm tree and the effectiveness of some systemic fungicides for their control., IV International Date Palm Conference.
Acta Horticulturae Number 882, pp. 505-514.

Bowen, K.L., 2006. Plant Disease Epidemiology, in: Trigiano, R.N., Windham, M.T., Windham, A.S. (Ed.), Plant Pathology, Concepts and Laboratory Exercises. CRC Press, Boca Raton London New York Washington, D.C.

Chaughtai, G.H., 1986. Annual report of insect pests of date palm and their control at D.I. Khan. Sindh Journal of Agriculture, 1-6.

Cook, W.B., 1963. A laboratory guide to fungi of polluted water, sewage and sewage system. Cincinnati Public Health Services, Pub, 1.

Eoin, L.N., 2016. Systematics: Blind dating. Nature Plants 2, 1-1.

Gilman, J.C., 1975. A manual of soil fungi. IOWA State College Press, USA.

Hussain, M., 2012. Impact of rainfall (humidity) on the development of fungal diseases on date plam (Phoenix dactylifer L.) fruit at ripening stage at district Khairpur Sindh, Pakistan. University of Sindh, pp. 103-105.

Hussain, M., Ismaili, N.J., 2019. Phytopathogenic fungi associated with ripening fruit of date palm (Phoenix dactylifera L.) during rainy season in the university area of Khairpur, Sindh, Pakistan. Plant Protection 3, 161-165.

Ishtique, M., Tarique, M., 1988. Physical properties of fruit, some indigence date palm cultivars grown at D.I. Khan. Sarhad Journal of Agriculture 4, 22712275.

Ismailli, N.J., 1999. Morphological and biochemical studies in dates at Khairpur. University of Sindh, pp. 87-88.

Ismailli, N.J., Muhammad, S., Zardari, M., 2003. Fungi occurring on dates (Phoenix dactytifera L) fruit during the rainy season in Khairpur district Sindh, Pakistan. Scientific Khyber 4, 110-111.

Ismailli, N.J., Soomro, A.Q., Zardari, M., Memon, M.S., Soomro, I., 1993. Fungi occurring on date palm, leaflets and inflorescence during rainy season in Khairpur. Scientific Sindh Annual Journal of Research, 1-9.

Jatoi, M.A., Markhand, Z., Solangi, N., 2009. Dates in Sindh: Facts and figures. , Proceedings of International Dates Seminar 28th July 2009, Khairpur, Sindh, Pakistan, pp. 59-72.

Khuskh, M.K., 1988. Role of different constituents in the development of date fruit of Khairpur district. 
University of Sindh, pp. 37-39.

Mahar, A.Q., 1998. Protection of date palm (Phoenix dactyllifera L. ) from monsoonic rain some measures in a district Khairpur, Sindh, Pakistan. Scientific Sindh 6, 7-8.

Mahar, A.Q., Bhatti, N.M., 1994. Protection of date palm (Phoenicx dactylifera L.) from moonsoonic rains in district Khairpur, Sindh, Pakistan. Scientific Sindh 2, 85-93.

Maitlo, W.A., Markhand, G.S., Abul-Soad, A.A., Lodhi, A.M., Jatoi, M.A., 2013. Chemical control of Fusarium solani causing sudden decline of date palm in Khairpur, Pakistan. Pakistan Journal of Botany 45(SI), 7-11.

Markhand, G.S., Abul-Soad, A.A., Mirbahar, A.A., Kanhar, N.A., 2010. Fruit characterization of Pakistani dates. Pakistan Journal of Botany 42, 3715-3722.

Sharma, K.R., Mukerji, K.G., 1976. Microbial ecology of Sesamum orientale L. and Gossypium hirsutum L.,
Microbiology of Aerial Plant Surfaces. Elsevier, pp. 375-390.

Siddiq, M., Aleid, S.M., Kader, A.A., 2013. Dates Postharvest Science, Processing Technology and Health Benefits. 1st Edition. New Delhi: WileyBlackwell, pp. 375-390.

Soomro, I.A., 1990. Isolation and identification of dermatophytes and other keratinophilic fungi from the soil of Shah Abdul Latif University Khairpur, Sindh, Pakistan Scientific Khyber 3 175182.

Thom, C., Raper, K.B.A., 1945. Manual of the Aspergillius, The William and Wikins Co. Baltimore.

Vidhyasekaran, P., 2004. Concise Encyclopedia of Plant Pathology. Food Products Press ${ }^{\circledR}$ and The Haworth Reference Press, imprints of The Haworth Press, Inc., 10 Alice Street, Binghamton, NY 13904-1580. 